\begin{tabular}{cc|c}
\hline Tar. Bil. Der. & Tarım Bilimleri Dergisi & Journal of Agricultural Sciences \\
& $\begin{array}{c}\text { Dergi web sayfası: } \\
\text { www.agri.ankara.edu.tr/dergi }\end{array}$ & Journal homepage: \\
& www.agri.ankara.edu.tr/journal
\end{tabular}

\title{
The Effects of Drying Methods, Packaging Atmosphere and Storage Time on Dried Pomegranate Aril Quality
}

\author{
Muharrem GÖLÜKCÜ ${ }^{a}$ \\ ${ }^{a}$ West Mediterranean Agricultural Research Institute, Demircikara Mahallesi Paşakavakları Caddesi No: 11, 07100, Muratpaşa, Antalya, \\ TURKEY
}

\section{ARTICLE INFO}

Research Article

DOI: 10.1501/Tarimbil_0000001323

Corresponding Author: Muharrem GÖLÜKCÜ, E-mail: muharrem98@yahoo.com, Tel: +90 (242) 3216797

Received: 13 June 2013, Received in Revised Form: 13 May 2014, Accepted: 30 June 2014

\begin{abstract}
The aim of this work was to evaluate the effects of drying methods, packaging atmosphere, and storage time in preserving the quality of dried pomegranate aril on total phenolic matter, total anthocyanin, antioxidant activity, and CIE L, a*, b*, $\mathrm{C}$, h colour values. The highest contents of phenolic matter $\left(5580 \mathrm{mg} \mathrm{kg}^{-1}\right)$, anthocyanin $\left(679.76 \mathrm{mg} \mathrm{kg}^{-1}\right)$, antioxidant capacity $\left(\mathrm{IC}_{50}, 26.16 \mathrm{mg} \mathrm{g}^{-1}\right)$ and $\mathrm{CIE} \mathrm{a*}$ colour value (10.73) were observed in freeze dried sample, followed by vacuum, convective, and sun dried samples in descending order. Phenolic matter, anthocyanin, antioxidant capacity $\left(1 / \mathrm{IC}_{50}\right)$ and CIE $\mathrm{a}^{*}, \mathrm{~b}^{*}, \mathrm{C}$ colour values of the samples packed under nitrogen gas were higher than those packed under air atmosphere. Significant changes in the quality parameters of the product were examined during storage, and the highest loss was determined in anthocyanin content among analyzed quality parameters. The result of present study indicated that freeze drying was the best method for dried pomegranate aril production.
\end{abstract}

Keywords: Pomegranate; Punica granatum; Dried pomegranate aril; Packaging; Storage stability

\section{Kurutulmuş Nar (Punica granatum) Danesi Kalitesi Üzerine Kurutma Metodu, Ambalajlama Atmosferi ve Depolama Süresinin Etkisi}

\section{ESER BILGISİ}

Araştırma Makalesi

Sorumlu Yazar: Muharrem GÖLÜKCÜ, E-posta: muharrem98@yahoo.com, Tel: +90 (242) 3216797

Geliş Tarihi: 13 Haziran 2013, Düzeltmelerin Gelişi: 13 Mayıs 2014, Kabul: 30 Haziran 2014

\section{ÖZET}

Bu çalışmanın amacı, nar dane kurusunun toplam fenolik madde, toplam antosiyanin, antioksidan aktivite ve CIE L, a*, b*, C ve h renk değerleri üzerine kurutma metodu, ambalajlama atmosferi ve depolama süresinin etkisini belirlemektir. Örnekler içerisinde en yüksek toplam fenolik madde miktarı (5580 mg kg-1), antosiyanin miktarı $\left(679.76 \mathrm{mg} \mathrm{kg}^{-1}\right)$, antioksidan aktivite $\left(\mathrm{IC}_{50}, 26.16 \mathrm{mg} \mathrm{g}^{-1}\right.$ ) ve $\mathrm{CIE} \mathrm{a*}$ renk değeri (10.73) dondurularak kurutulmuş olan nar dane kurusu örneklerinde belirlenmiş ve bunu sırasıyla vakumlu firında, hava sirkülasyonlu firında ve güneşte kurutulan örnekler takip etmiştir. Azot gazı altında paketlenen örneklerin kalitesi atmosfer ortamında paketlenenlere göre daha yüksek 
toplam fenolik madde, toplam antosiyanin, antioksidan aktivite ve CIE L, a*, b*, C ve h renk değerlerine sahip olduğu görülmüştür. Depolama süresince analiz edilen kalite parametreleri arasında en fazla kayıp antosiyanin içeriğinde belirlenmiştir. Çalışmadan elde edilen sonuçlar, nar dane kurusu üretimi için en uygun yöntemin dondurarak kurutma olduğunu göstermiştir.

Anahtar Kelimeler: Nar; Punica granatum; Nar dane kurusu; Paketleme; Raf stabilitesi

(C) Ankara Üniversitesi Ziraat Fakültesi

\section{Introduction}

Pomegranate (Punica granatum) is widely cultivated in Middle East, the Mediterranean countries and the United States (Schubert et al 1999). Turkey is one of the major pomegranate producing countries in the world. Pomegranate production has rapidly increased after 1990 in Turkey. While pomegranate production was 10000 tones in 1990, it reached to 208502 tones in 2011 (TUIK 2012).

Pomegranate is commonly consumed as freshly and also processed into juice, concentrate, sour and syrup, etc. (Gil et al 1996; Vardin 2000; Vardin \& Abbasoğlu 2004). Consumption of the fruit and its products steadily increased in the world due to the awareness of its functional properties. Pomegranate is rich in phenolic compounds (anthocyanins), conjugated linolenic acid (especially punicic acid in pomegranate seed oil), minerals and vitamins (vitamin C, pantothenic acid and vitamin B6). Phenolic compounds have antioxidant properties and they play a role in preventing cancer and cardiovascular disease by preventing free radical formation in the body (Gil et al 2000; Poyrazoğlu et al 2002; Fadavi et al 2006; Kiralan et al 2009). Additionally, it has been reported that punicic acid, which is the major fatty acid of the pomegranate seed, has prevention effects on prostate and skin cancers and lipid level lowering effect in liver (Hora et al 2003; Albrecht et al 2004).

The most important group of phenolic compounds in pomegranate fruit is anthocyanins which are responsible for the characteristic red colour of pomegranate products (Hernandez et al 1999). The stability of anthocyanins depends on many factors such as temperature, $\mathrm{pH}$, light, oxygen and ascorbic acid addition, etc. (Cemeroğlu \& Artık 1990; Asafi
\& Cemeroğlu, 2000). In recent years, there are some limited research on dried pomegranate arils. Calín-Sanchez et al (2013) carried out a study on some quality parameters of dried pomegranate aril. In this study, Mollar de Elche cultivar was dried by four different methods (convective drying, freeze drying, vacuum-microwave drying and a comined method of convective and microwave drying). Some organic acids, sugars, phenolic compounds, antioxidant activity and sensory analysis were carried out in these products to evaluate the effects of drying methods. As a result, vacuum-microwave drying at 240 or $260 \mathrm{~W}$ was found as the best drying treatment for arils. Another study on dried pomegranate aril was carried out by Jaisval et al (2010) in order to determine the effect of drying on anthocyanin content of pomegranate aril and investigate the role of polyphenoloxidase activity in aril anthocyanin oxidation. Consequently, they found that anthocyanins adversely affected by drying, and polyphenoloxidase playing a possible role in anthocyanins degradation. One another study showed that dried pomegranate aril has high nutritional elements (Kingsly et al 2006). As a conclusion, pomegranate products (dried pomegranate aril etc.), which contain seeds, are more healthier than juice like products because of the high nutritional value of the pomegranate seed. On the other hand, there is no study on colour values, anthocyanin content with respect to drying methods, packaging atmosphere and storage time. To the best of my knowledge, there is no research conducted on dried pomegranate aril production from pomegranate cultivars grown in Turkey.

The aim of this research was to investigate the possibility of processing of the Hicaznar, which has the highest production and export quantity in 
Turkey, into dried pomegranate arils. In this study, the effects of four different drying processes [sun drying (SD), convective hot-air oven drying (CD), vacuum oven drying (VD) and freeze drying (FD)], and packaging atmosphere during 12 months storage time were investigated on total phenolic matter, anthocyanin, antioxidant activity and CIE L, $a^{*}, b^{*}, C, h$ colour values of the products.

\section{Material and Methods}

This research was carried out on Food Technology Department of Batı Akdeniz Agricultural Research Institute in Antalya, Turkey. Approximately $100 \mathrm{~kg}$ of fully mature and medium size fruit from Hicaznar cultivar was harvested by hand on 24 October 2011. In order to determine the properties of raw materials, the mean fruit weight, aril weight, aril ratio to fruit, $\mathrm{pH}$, titratable acidity, water soluble solids, total dry matter, CIE L, a*, b*, chroma (C) and hue angle (h) color parameters, total anthocyanin, phenolic matter content and antioxidant activity (DPPH) were determined. After that, the fruits were cut into four-six parts by stainless steel knife and then arils separated by hand without damaging. Finally, these fresh arils (initial moisture content of the arils was $76.96 \%$ wet basis) dried by four different drying methods. Drying process has been maintained until the water activity value of the products reached to 0.55 (final moisture content 10\%). Four drying methods (sun drying, convective hot-air oven drying, vacuum oven drying, and freeze drying) were investigated.

Convective hot-air oven drying of pomegranate arils was conducted in a cabinet dryer (Venticell-404 Standard, MMM group, Germany) in thin layer. The dryer consisted of trays, temperature controller (up to $\left.300{ }^{\circ} \mathrm{C}\right)$ and a fan for airflow $\left(7.272 \mathrm{~m}^{3}\right.$ hour $\left.{ }^{-1}\right)$. Drying process was performed at $55{ }^{\circ} \mathrm{C}$ for 24 hours. Vacuum oven drying process was conducted in cabinet dryer (Vacucell VUS-B2V/VU, MMM group, Germany). The dryer consisted of trays, temperature (up to $200^{\circ} \mathrm{C}$ ) and vacuum controller. Drying process was performed at $55{ }^{\circ} \mathrm{C}$ for 24 hours at $3.5 \mathrm{kPa}$ pressures. Sun drying experiments were performed in October and November 2011 in Antalya. The experiment was located on the open top floor of a four-floor building to have direct sun radiation for 14 days.

Drying process by freeze dryer (Christ Beta 2-8 LD plus) was applied at two stages. Primary drying was applied at $-20^{\circ} \mathrm{C}, 0.1 \mathrm{kPa}$ for 12 hours. And, secondary drying stage was applied at $-70{ }^{\circ} \mathrm{C}$, $0.00026 \mathrm{kPa}$ for 24 hours. Products were packed hermetically under nitrogen and air atmosphere into $190 \mathrm{~mL}$ glass jar (approximately $100 \mathrm{~g}$ ) and stored at room temperature.

CIE $\mathrm{L}, \mathrm{a}^{*}, \mathrm{~b}^{*}, \mathrm{C}$ and $\mathrm{h}$ color values, total anthocyanin, total phenolic matter content and antioxidant activity parameters were analyzed during 12 months within one month intervals. Titratable acidity was done with titrimetric method, and the results were expressed as anhydrous citric acid (Cemeroğlu 2010). To determine the overall nutritional content of the products, protein (Egan et al 1981), oil content (AOAC 2005) and mineral matter composition (Varian 1989) of the products were analyzed. Minerals contents (K, Ca, Mg, P, Fe, $\mathrm{Zn}$ and $\mathrm{Mn}$ ) were determined by ICP (Varian).

CIE L, a*, b*, chroma (C) and hue angle (h) colour values of the samples measured by using Minolta CR 400 apparatus. All colour values were measured by using $\mathrm{D}_{65}$ light source. The colour meter was calibrated by white calibration plate (CR-A43) at the beginning of the measurement (Özdemir 2001). Total anthocyanin (T.Ant.) content of the samples was determined by $\mathrm{pH}$ differential methods (AOAC 2005). Extraction was carried out using acidified methanol (methanol: $2 \% \mathrm{HCl}$ ) according to Michalczyk et al (2009). Firstly, 10 $\mathrm{mL}$ of the solvent was added to the dry matter (approximately $5 \mathrm{~g}$ ) and homogenized (IKA, T25 Digital Ultra-turrax, Germany), and then shaked (Heidolp, Unimax 2010, Germany) for 20 minutes. Finally, this extract was centrifuged for 5 minutes at $5000 \mathrm{rpm}$. After the residue was extracted using the same procedure twice more, these extracts were combined. Total anthocyanin content of the extracts was measured at 520 and $700 \mathrm{~nm}$ by using UV-Vis spectrophotometer (Shimadzu, UV-1800, Japan), and the results were expressed as cyanidin3-glycoside (AOAC 2005). Total phenolic matter 
(TPM) content was determined by using Spanos \& Wrolstad (1990) method. Samples were extracted by methanol at three steps according to Escarpa \& Gonzales (2001). Briefly, approximately $5 \mathrm{~g}$ of the arils were extracted twice with $10 \mathrm{~mL}$ of pure methanol for 1 hour, $10 \mathrm{~mL}$ for 30 minute, and then $5 \mathrm{~mL}$ for 30 minute in an ultrasonic bath at room temperature. The extracts were combined and phenolic content of these extracts were measured at $765 \mathrm{~nm}$ by using UV-Vis spectrophotometer. The results for phenolic contens were expressed as gallic acid equivalent by using standard calibration curve of this phenolic compound. Antioxidant activities (AA) of the samples were determined by DPPH method (Lafka et al 2007). Antioxidant capacity of these extract (same as total phenolic matter extraction procedure) was measured at 515 $\mathrm{nm}$ by spectrophotometer. Results were calculated as inhibition capacity $\left(\mathrm{IC}_{50}\right)$.

The experiment was conducted with two replications. Analyses were conducted in two parallel, and obtained results were subjected to statistical analysis by using the SAS software packed program. The significance of the effects of drying methods, packaging atmosphere and storage time, as well as, their interactions on the measured variables was estimated by three-way factorial analysis of variance (ANOVA). Results were evaluated by Duncan's Multiple Comparison Test. Result were given as mean \pm standard error (SE).

\section{Results and Discussion}

Some physical and chemical properties of the raw material were given in Table 1. The mean fruit weight of Hicaznar cultivar was measured as 673 $\mathrm{g}$ and aril ratio was calculated as $47.55 \%$. And, one thousand weight of the aril was determined as $413 \mathrm{~g}$ for this cultivar. Color is the major criteria effecting the consumer acceptance. CIE L, a* $\mathrm{b}^{*}, \mathrm{C}$ and $\mathrm{h}$ colour values of the unprocessed pomegranate aril were measured and given in Table 1. CIE L, a*, $\mathrm{b}^{*}$ colour values were determined as $36.26,14.05$, and 6.46 respectively. Chroma and hue angle values were 15.47 and 24.70 for raw material.

Some chemical properties of the raw material were also determined. Titratable acidity of the sample was determined as $1.35 \%$ (anhydrous citric acid). Soluble dry matter, total dry matter, oil and ash content of pomegranate aril were determined as $16^{\circ}$ Brix, $23.04 \%, 1.54 \%, 0.57 \%$, respectively. The oil content of the samples sourced from seed content of the aril (Gölükcü et al 2008).

In this study, total phenolic matter, anthocyanin and antioxidant capacity of the samples were analyzed in the raw material and dried products. Total phenolic content of the fresh aril was determined as $658.25 \mathrm{mg} \mathrm{kg}^{-1}$. One of the most important quality parameters and also valuable constituent for nutrition is anthocyanins for pomegranate products (Hernandez et al 1999; Du et al 1975). Total anthocyanin content of the samples was recognized

Table 1- Some physical and chemical properties of Hicaznar cultivar

Çizelge 1- Hicaznar çeşidinin bazı fiziksel ve kimyasal özellikleri

\begin{tabular}{llll}
\hline Physical properties & & Chemical properties \\
\hline Parameters & (Mean \pm S.D) & Parameters & (Mean \pm S.D) \\
\hline Fruit weight $(\mathrm{g})$ & $673 \pm 65.4$ & Titratable acidity $(\%)$ & $1.35 \pm 0.12$ \\
Aril weight g fruit ${ }^{-1}$ & $320 \pm 20.5$ & Water soluble dry matter $\left({ }^{\circ} \mathrm{Brix}\right)$ & $16.00 \pm 0.35$ \\
1000 aril weight $(\mathrm{g})$ & $413 \pm 26.5$ & Total dry matter $(\%)$ & $23.04 \pm 0.52$ \\
$\mathrm{~L}$ & $36.26 \pm 0.32$ & Total oil $(\%)$ & $1.54 \pm 0.14$ \\
$\mathrm{a}^{*}$ & $14.05 \pm 0.25$ & Total ash $(\%)$ & $0.57 \pm 0.02$ \\
$\mathrm{~b}^{*}$ & $6.46 \pm 0.18$ & Total phenolic matter $\left(\mathrm{mg} \mathrm{kg}^{-1}\right)$ & $658.25 \pm 12.45$ \\
Chroma $(\mathrm{C})$ & $15.47 \pm 0.23$ & Total anthocyanin $\left(\mathrm{mg} \mathrm{kg}^{-1}\right)$ & $376.91 \pm 8.96$ \\
Hue angle $(\mathrm{h})$ & $24.70 \pm 0.27$ & Antioxidant activity $\left(\mathrm{IC}_{50}, \mathrm{mg} \mathrm{g}^{-1}\right)$ & $42.00 \pm 0.94$ \\
\hline
\end{tabular}

S.D, standard deviation 
as $376.91 \mathrm{mg} \mathrm{kg}^{-1}$. The antioxidant capacity of the samples was determined as $42 \mathrm{mg} \mathrm{g}^{-1}$.

In order to determine some nutritional properties of the dried pomegranate arils, protein, oil and some mineral contents were analyzed and given in Table 2. Total protein and oil content of the dried samples ranged between 7.24-7.38\%, 6.25-6.30\%, respectively. These values showed that dried pomegranate arils were rich in these nutritional components. Oil and protein content of Hicaznar seeds were determined in our previous study as $21.03 \%, 14.91 \%$ on dry matter base, respectively (Gölükcü et al 2008).

Results of some macro and micro mineral contents of the samples showed some differences between drying methods. This could be sourced from differences in drying process parameters. Sun dried products could be contaminated with dust or similiar agents because of the process conditions. Freeze dried samples physically damaged during the process, and this could be resulted in some compositional differences. Phosphorus, potassium, calcium and magnesium contents of the samples ranged between 952-1072 $\mathrm{mg} \mathrm{kg}^{-1}, 1719-1847$ $\mathrm{mg} \mathrm{kg}^{-1}, 82.47-92.19 \mathrm{mg} \mathrm{kg}^{-1}$ and 89.52-96.17 mg $\mathrm{kg}^{-1}$, respectively. Mineral matters were also highly found in seed part of the aril. In fact, provious works has shown that pomegranate seeds were very rich in terms of mineral matters. The mineral content of the pomegranate seeds was $0.308-1.399 \%$ for $\mathrm{K}, 0.252$ $0.650 \%$ for $\mathrm{P}, 0.143-0.281 \%$ for $\mathrm{Ca}, 0.107-0.276 \%$ for Mg (Gölükcü et al 2008). The analyzed micro nutrient elements, $\mathrm{Fe}, \mathrm{Mn}$ and $\mathrm{Zn}$ contents of the samples were ranged between $0.34-0.36 \mathrm{mg} \mathrm{kg}^{-1}$, $0.89-0.96 \mathrm{mg} \mathrm{kg}^{-1}, 3.18-3.93 \mathrm{mg} \mathrm{kg}^{-1}$ in same order.

Probabilities of the effects of drying methods (DM), packaging atmosphere (PA), storage time and their interactions on total phenolics (TPM), total anthocyanin (T.Ant.), antioxidant activity (AA) in dried pomegranate arils were given in Table 3 .

The effect of drying method, packaging atmosphere and storage time interaction on total phenolic matter content of the samples were statistically significant. Total phenolic matter contents of the dried samples according to drying, packaging atmosphere and storage time were given in Table 4 and Figure 1. At the beginning of storage, the highest total phenolic matter was determined

Table 2- Protein (\%), oil (\%) and some mineral content $\left(\mathrm{mg} \mathrm{kg}^{-1}\right)$ of the products (mean $\left.\pm \mathrm{SE}\right)$

Çizelge 2- Örneklerin protein (\%), yağ (\%) ve bazı mineral madde ( $\mathrm{mg} \mathrm{kg}^{-1}$ ) içeriği (ortalama \pm SH)

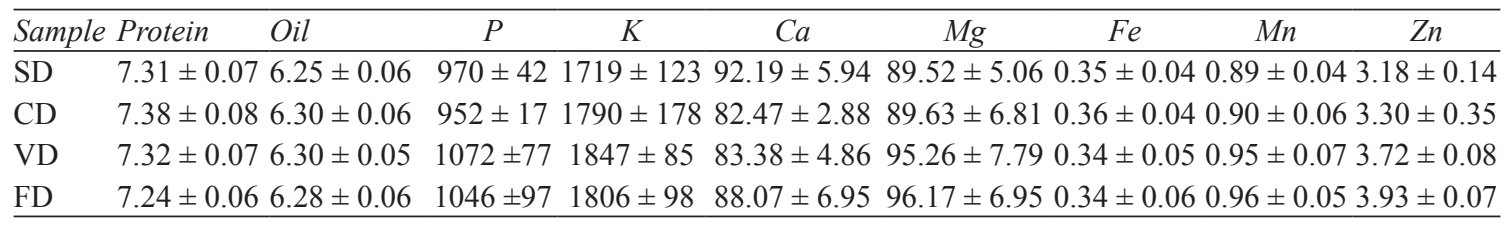

Table 3- ANOVA results for all measured quality parameters (probabilities)

Çizelge 3- Ölçümü yapılan kalite parametrelerinin ANOVA sonuçları

\begin{tabular}{lllllllll}
\hline Factors & $T P M$ & T.Ant. & A.A. & $L$ & $a^{*}$ & $b^{*}$ & $C$ & $h$ \\
\hline Drying method (DM) & $* *$ & $* *$ & $* *$ & $* *$ & $* *$ & $* *$ & $* *$ & $* *$ \\
Packaging atmospher (PA) & $* *$ & $* *$ & $* *$ & NS & $* *$ & $* *$ & $* *$ & NS \\
Storage time (ST) & $* *$ & $* *$ & $* *$ & NS & $* *$ & $* *$ & $* *$ & $* *$ \\
DMxPA & $* *$ & NS & NS & NS & $* *$ & NS & $* *$ & $* *$ \\
DMxST & $* *$ & $* *$ & NS & NS & NS & NS & NS & $* *$ \\
PAxST & $* *$ & $*$ & NS & NS & NS & NS & NS & NS \\
DMxPAxST & $* *$ & NS & NS & NS & NS & NS & NS & NS \\
\hline
\end{tabular}

NS, not significant; *, significant at $\mathrm{P}<0.05$; **, significant at $\mathrm{P}<0.01$ 
in the samples dried by freeze dryer, followed by vacuum oven, convective oven, and sun dried samples. The lowest phenolic content in sun dried samples could be resulted from the oxidation of phenolic compounds under long drying process, which taken place for 14 days. Phenolic content of plant materials depends on cultural practices, cultivar, ripening process, as well as processing and storage condition (Naczk \& Shahidi 2006). CalinSanchez et al (2013) found the total phenolic content of the dried pomegranate aril, produced from Mollar de Elche cultivar, ranged between 1.57-2.51 mg eq gallic acid $\mathrm{g}^{-1}$. These values are lower than our findings. This could be sourced from pomegranate cultivar difference. Sogi et al (2013) investigated the effects of drying methods (freeze drying, hot air drying, vacuum drying and infrared drying) on phenolic content of mango peel and kernel. They found that freeze dried samples had the highest total phenolic content followed by vacuum, hot air and infrared dried samples. This result is consistent with our results. Kingsly \& Singh (2007) reported that drying process has a great effect on the quality of dried arils. Additionaly, they reported the sun drying has some disadvantages such as time consumption, contamination with dust and insects, and also weather dependent. Total phenolic content of the sample under nitrogen is higher than other one. Christopoulos \& Tsantili (2011) observed that, total phenolic loss in dried walnuts during the storage under nitrogen gas were lower than atmospheric oxygen. Our finding is in line with this literature results. This could be sourced from oxidation effects of oxygen on phenolic compounds.

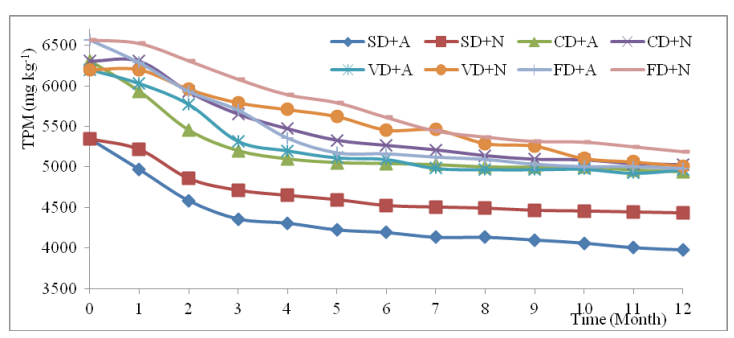

Figure 1- Total phenolic matter content of dried pomegranate aril with respect to drying process, packaging atmosphere and storage time

Şekil 1- Kurutma yöntemi, paketleme atmosferi ve depolama süresine göre örneklerin toplam fenolik madde içerikleri

Table 4- Duncan multiple comparision test result of total phenolic matter contents $\left(\mathrm{mg} \mathrm{kg}^{-1}\right) \mathrm{of} \mathrm{dried}^{-1}$ pomegranate aril with respect to drying process $x$ packaging atmosphere $x$ storage time (mean $\pm \mathrm{SE}$ )

Çizelge 4- Kurutma yöntemi x paketleme atmosferi $x$ depolama süresine göre örneklerin toplam fenolik madde içeriklerine $\left(\mathrm{mg} \mathrm{kg}^{-1}\right)$ ait duncan çoklu karşılaştırma testi sonuçları (ortalama \pm SH)

\begin{tabular}{|c|c|c|c|c|c|c|c|c|}
\hline \multirow{2}{*}{ ST } & \multicolumn{2}{|c|}{ Sun drying } & \multicolumn{2}{|c|}{ Convective drying } & \multicolumn{2}{|c|}{ Vacuum drying } & \multicolumn{2}{|c|}{ Freeze drying } \\
\hline & Air & Nitrogen & Air & Nitrogen & Air & Nitrogen & Air & Nitrogen \\
\hline 0 & $5345^{\mathrm{aA}} \pm 49$ & $5345^{\mathrm{aA}} \pm 49$ & $6310^{\mathrm{aAB}} \pm 87$ & $6310^{\mathrm{aAB}} \pm 87$ & $6204^{\mathrm{aB}} \pm 56$ & $6204^{\mathrm{aB}} \pm 56$ & $6567^{\mathrm{aC}} \pm 129$ & $6567^{\mathrm{aC}} \pm 129$ \\
\hline 1 & $4969^{\mathrm{bE}} \pm 54$ & $5215^{\mathrm{bD}} \pm 29$ & $5935^{\mathrm{bC}} \pm 39$ & $6309^{\mathrm{aB}} \pm 53$ & $6033^{\mathrm{bC}} \pm 59$ & $6203^{\mathrm{aB}} \pm 8$ & $6286^{\mathrm{bB}} \pm 34$ & $6525^{\mathrm{aA}} \pm 53$ \\
\hline 2 & $4585^{\mathrm{cF}} \pm 41$ & $4857^{\mathrm{CE}} \pm 55$ & $5455^{\mathrm{cD}} \pm 47$ & $5929^{\mathrm{bBC}} \pm 45$ & $5776^{\mathrm{cC}} \pm 28$ & $5961^{\mathrm{bB}} \pm 27$ & $5932^{\mathrm{cBC}} \pm 82$ & $6310^{\mathrm{bA}} \pm 14$ \\
\hline 3 & $4360^{\mathrm{dE}} \pm 56$ & $4712^{\mathrm{dD}} \pm 47$ & $5201^{\mathrm{dC}} \pm 84$ & $5653^{\mathrm{cB}} \pm 111$ & $5320^{\mathrm{dC}} \pm 69$ & $5795^{\mathrm{bcB}} \pm 71$ & $5701^{\mathrm{dB}} \pm 35$ & $6083^{\mathrm{cA}} \pm 58$ \\
\hline 4 & $4308^{\mathrm{deF}} \pm 10$ & $4649^{\mathrm{deE}} \pm 30$ & $5099^{\mathrm{deD}} \pm 36$ & $5473^{\mathrm{dC}} \pm 13$ & $5203^{\mathrm{deD}} \pm 61$ & $5711^{\mathrm{cB}} \pm 66$ & $5355^{\mathrm{eC}} \pm 56$ & $5892^{\mathrm{dA}} \pm 44$ \\
\hline 5 & $4225^{\mathrm{efE}} \pm 13$ & $4596^{\mathrm{defD}} \pm 62$ & $5053^{\mathrm{deC}} \pm 32$ & $5330^{\mathrm{deB}} \pm 49$ & $5117^{\mathrm{efC}} \pm 26$ & $5625^{\mathrm{cdA}} \pm 95$ & $5174^{\mathrm{efBC}} \pm 73$ & $5794^{\mathrm{dA}} \pm 15$ \\
\hline 6 & $4192^{\mathrm{efgF}} \pm 36$ & $4524^{\mathrm{efgE}} \pm 36$ & $5042^{\mathrm{deD}} \pm 15$ & $5267^{\mathrm{efC}} \pm 40$ & $5096^{\mathrm{ePD}} \pm 41$ & $5459^{\mathrm{deB}} \pm 31$ & $5162^{\mathrm{efCD}} \pm 52$ & $5612^{\mathrm{eA}} \pm 78$ \\
\hline 7 & $4134^{\mathrm{fghF}} \pm 22$ & $4505^{\mathrm{fgE}} \pm 7$ & $5028^{\mathrm{eCD}} \pm 17$ & $5211^{\mathrm{efgB}} \pm 50$ & $4986^{\mathrm{fgD}} \pm 23$ & $5462^{\mathrm{deA}} \pm 32$ & $5121^{\mathrm{fBC}} \pm 23$ & $5445^{\mathrm{efA}} \pm 51$ \\
\hline 8 & $4134^{\mathrm{fghE}} \pm 43$ & $4491^{\mathrm{fgD}} \pm 19$ & $5000^{\mathrm{eC}} \pm 11$ & $5140^{\mathrm{fghB}} \pm 16$ & $4971^{\mathrm{fgC}} \pm 33$ & $5292^{\mathrm{efA}} \pm 80$ & $5093^{\mathrm{fBC}} \pm 45$ & $5371^{\mathrm{fgA}} \pm 2$ \\
\hline 9 & $4100^{\mathrm{ghE}} \pm 12$ & $4464^{\mathrm{fgD}} \pm 32$ & $4997^{\mathrm{eC}} \pm 86$ & $5095^{\mathrm{fgh} A B C} \pm 61$ & $4970^{\mathrm{fgC}} \pm 62$ & $5260^{\mathrm{efg} A B} \pm 136$ & $5033^{\mathrm{fBC}} \pm 32$ & $5317^{\mathrm{fgA}} \pm 50$ \\
\hline 10 & $4062^{\mathrm{hDD}} \pm 40$ & $4456^{\mathrm{gC}} \pm 48$ & $4996^{\mathrm{eB}} \pm 33$ & $5087^{\mathrm{fghB}} \pm 40$ & $4976^{\mathrm{fgB}} \pm 28$ & $5107^{\mathrm{fghB}} \pm 27$ & $5005^{\mathrm{fB}} \pm 54$ & $5308^{\mathrm{fgA}} \pm 74$ \\
\hline 11 & $4006^{\mathrm{IF}} \pm 17$ & $4444^{\mathrm{gE}} \pm 46$ & $4962^{\mathrm{eCD}} \pm 27$ & $5041^{\mathrm{ghBC}} \pm 23$ & $4926^{\mathrm{fgD}} \pm 25$ & $5065^{\mathrm{ghB}} \pm 39$ & $5004^{\mathrm{fBCD}} \pm 17$ & $5251^{\mathrm{gA}} \pm 13$ \\
\hline 12 & $3979^{1 \mathrm{D}} \pm 43$ & $4431^{\mathrm{gC}} \pm 34$ & $4938^{\mathrm{eB}} \pm 37$ & $5028^{\mathrm{hAB}} \pm 16$ & $4968^{\mathrm{gB}} \pm 72$ & $5013^{\mathrm{hAB}} \pm 90$ & $4979^{\mathrm{fB}} \pm 68$ & $5190^{\mathrm{gA}} \pm 21$ \\
\hline
\end{tabular}

A-F, mean in the same row with different upper case letters are significantly different $(\mathrm{P}<0.05)$; ${ }^{\mathrm{a}-1}$, mean in the same column with different lower case letters are significantly different $(\mathrm{P}<0.05)$ 
Phenolic content of the dried arils significantly reduced during storage in each samples (Table 4). During storage, there were significant differences between drying methods and packaging methods of each drying methods with respect to total phenolic matter contents. In addition to this results, statistical differences were also found between each treatments. These results could be explained by the fact that, individual applications of each factors were not enough to prevent changes in the total phenolic contents during storage compared with combined treatments. As a result, to control total phenolic loss in dried pomegranate aril during storage combined treatments is a good way compared to each applications alone. There is no publications on the influence of storage conditions on phenolic, antioxidant, and colour values of dried pomegranate arils. But, some reports are available in the literature on these quality parameters of some other food products. Tsantili et al (2011) studied the effects of storage time on total phenolic content of dried pistachio nuts. They observed that totally there was $24.7 \%$ loss in total phenolic content of the samples. Maier et al (2009) also reported that there were significant decreases in total phenolic and anthocyanin contents during storage. While there was significant decreasing in phenolic content of dried pomegranate aril, this product was still rich for phenolics.

Anthocyanins are one of the most important compounds group in pomegranate fruit. Anthocyanin content changes of the samples with repect to drying methods, packaging atmosphere and storage time were given in Figure 2. Drying methods $\mathrm{x}$ storage time and packaging atmosphere had also significant effect on anthocyanin content (Table 5). At the beginning of storage, the highest anthocyanin content were determined in freeze dried samples, followed by vacuum oven, convective oven and sun dried samples in descending order. Jaiswal et al (2010) carried out a research on the effects of sun drying and convective drying on some quality parameters of pomegranate aril and noted that anthocyanin content of the fresh aril was $250.5 \mathrm{mg} \mathrm{kg}^{-1}$, which was reduced to $97.4 \mathrm{mg}$ $\mathrm{kg}^{-1}$ in convective dried and to $42.2 \mathrm{mg} \mathrm{kg}^{-1}$ in sun dried arils. This research showed that anthocyanin

Table 5- Duncan multiple comparision test result of total anthocyanin contents (mg $\left.\mathrm{kg}^{-1}\right) \mathrm{of} \mathrm{dried}^{-1}$ pomegranate aril with respect to drying process $x$ storage time and packaging atmospherexstorage time $($ mean $\pm \mathrm{SE})$

Çizelge 5- Kurutma yöntemi $x$ depolama süresi ve paketleme atmosferi x depolama süresine göre örneklerin toplam antosiyanin içeriklerine $\left(\mathrm{mg} \mathrm{kg}^{-1}\right)$ ait duncan çoklu karşılaştırma testi sonuçları (ortalama \pm SH)

\begin{tabular}{|c|c|c|c|c|c|c|}
\hline \multirow{2}{*}{$\begin{array}{c}\text { Storage } \\
\text { time }\end{array}$} & \multicolumn{4}{|c|}{ Drying methods } & \multicolumn{2}{|c|}{ Packaging atmosphere } \\
\hline & $S D$ & $C D$ & $V D$ & $F D$ & Air & Nitrogen \\
\hline 0 & $318.81^{\mathrm{aD}} \pm 6.67$ & $490.41^{\mathrm{aC}} \pm 5.03$ & $603.41^{\mathrm{aB}} \pm 6.38$ & $1288.73^{\mathrm{aA}} \pm 15.73$ & $675.3^{\mathrm{aA}} \pm 139.36$ & $675.3^{\mathrm{aA}} \pm 139.36$ \\
\hline 1 & $214.67^{\mathrm{bD}} \pm 17.02$ & $471.93^{\mathrm{aC}} \pm 11.65$ & $541.21^{\mathrm{bB}} \pm 15.88$ & $1176.72^{\mathrm{bA}} \pm 34.26$ & $574.6^{\mathrm{abA}} \pm 131.57$ & $627.7^{\mathrm{abA}} \pm 136.63$ \\
\hline 2 & $193.73^{\mathrm{bcD}} \pm 11.99$ & $427.55^{\mathrm{bC}} \pm 12.11$ & $493.85^{\mathrm{CB}} \pm 12.12$ & $1115.65^{\mathrm{cA}} \pm 24.37$ & $536.9^{\mathrm{abA}} \pm 127.17$ & $578.5^{\mathrm{abcA}} \pm 130.86$ \\
\hline 3 & $175.18^{\mathrm{cdD}} \pm 10.34$ & $400.30^{\mathrm{bC}} \pm 10.61$ & $448.09^{\mathrm{dB}} \pm 15.91$ & $1051.81^{\mathrm{dA}} \pm 19.77$ & $498.1^{\mathrm{abcA}} \pm 120.67$ & $539.8^{\mathrm{a}-\mathrm{dA}} \pm 124.80$ \\
\hline 4 & $160.04^{\mathrm{deC}} \pm 11.70$ & $364.37^{\mathrm{cB}} \pm 9.21$ & $404.98^{\mathrm{eB}} \pm 11.06$ & $861.66^{\mathrm{eA}} \pm 23.02$ & $427.8^{\mathrm{a}-\mathrm{dA}} \pm 94.03$ & $467.7^{\mathrm{a}-\mathrm{eA}} \pm 100.04$ \\
\hline 5 & $135.55^{\mathrm{efD}} \pm 16.37$ & $312.99^{\mathrm{dC}} \pm 8.19$ & $375.52^{\mathrm{efB}} \pm 11.56$ & $819.22^{\mathrm{eA}} \pm 19.71$ & $404.4^{\mathrm{a}-\mathrm{dA}} \pm 103.06$ & $417.2^{\mathrm{a}-\mathrm{fA}} \pm 87.46$ \\
\hline 6 & $111.16^{\mathrm{fgD}} \pm 9.35$ & $283.11^{\mathrm{eC}} \pm 10.61$ & $351.22^{\mathrm{fB}} \pm 11.89$ & $714.82^{\mathrm{fA}} \pm 12.72$ & $349.5^{\mathrm{b}-\mathrm{eA}} \pm 83.46$ & $380.7^{\mathrm{b}-\mathrm{gA}} \pm 83.22$ \\
\hline 7 & $101.74^{\mathrm{gD}} \pm 10.28$ & $253.36^{\mathrm{fC}} \pm 10.47$ & $306.34^{\mathrm{gB}} \pm 12.53$ & $564.37^{\mathrm{gA}} \pm 14.57$ & $294.9^{\mathrm{b}-\mathrm{eA}} \pm 61.97$ & $318.5^{\mathrm{c}-\mathrm{gA}} \pm 64.72$ \\
\hline 8 & $89.23^{\mathrm{ghC}} \pm 9.92$ & $222.57^{\mathrm{gB}} \pm 6.64$ & $253.41^{\mathrm{hB}} \pm 13.59$ & $465.61^{\mathrm{hA}} \pm 17.20$ & $241.7^{\mathrm{cdeA}} \pm 49.58$ & $273.7^{\mathrm{d}-\mathrm{gA}} \pm 52.98$ \\
\hline 9 & $77.78^{\mathrm{ghD}} \pm 8.94$ & $178.14^{\mathrm{hC}} \pm 6.26$ & $226.76^{\mathrm{hBB}} \pm 10.94$ & $345.96^{1 \mathrm{~A}} \pm 7.15$ & $195.6^{\mathrm{deA}} \pm 38.01$ & $218.7^{\operatorname{efg} A} \pm 35.34$ \\
\hline 10 & $65.13^{\mathrm{hj} \mathrm{D}} \pm 9.01$ & $155.02^{\mathrm{hiC}} \pm 14.01$ & $200.62^{\mathrm{j} \mathrm{B}} \pm 4.27$ & $237.99^{\mathrm{jA}} \pm 4.50$ & $155.6^{\mathrm{deA}} \pm 27.01$ & $173.7^{\mathrm{fgA}} \pm 22.48$ \\
\hline 11 & $53.89^{\mathrm{ijC}} \pm 8.71$ & $127.43^{\mathrm{jB}} \pm 10.20$ & $171.23^{\mathrm{jkB}} \pm 10.38$ & $115.15^{\mathrm{kA}} \pm 7.48$ & $105.1^{\mathrm{eA}} \pm 16.22$ & $128.6^{\mathrm{fgA}} \pm 16.54$ \\
\hline 12 & $35.07^{\mathrm{iD}} \pm 7.41$ & $113.73^{\mathrm{jC}} \pm 9.50$ & $145.36^{\mathrm{kB}} \pm 6.89$ & $79.15^{\mathrm{kA}} \pm 2.23$ & $84.4^{\mathrm{eA}} \pm 15.78$ & $102.3^{\mathrm{gA}} \pm 15.79$ \\
\hline
\end{tabular}

A-D , mean in the same row with different upper case letters are significantly different $(\mathrm{P}<0.05)$ between each storage time of drying methods; ${ }^{\mathrm{a}-\mathrm{j}}$, mean in the same column with different letters are significantly different $(\mathrm{P}<0.05)$ 
content of the samples lost during drying process. Our findings also showed that anthocyanin content of the samples except for freeze drying decreased as compared with fresh one on dry matter base. The differences in other value could be resulted from the cultivar difference used in dried aril production and also process parameters variances.

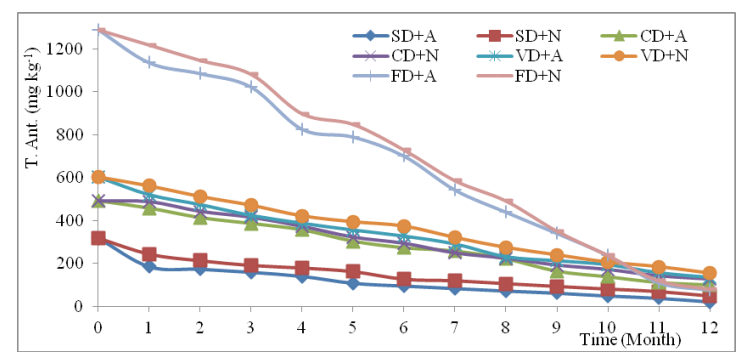

Figure 2-Anthocyanin content of dried pomegranate aril with respect to drying process, packaging atmosphere and storage time

Şekil 2- Kurutma yöntemi, paketleme atmosferi ve depolama süresine göre örneklerin toplam antosiyanin içerikleri

Total anthocyanin content of the samples stored under nitrogen gas atmosphere was higher than those of the samples stored under atmospheric condition during storage period. Jaiswal et al (2010) reported that there was about $65 \%$ loss of cyanidin-3-glucoside in the sample maintained under air. Another study was carried out by Perez-Vicente et al (2004) on influence of packaging material on anthocyanin content of pomegranate juice. The higher anthocyanin loss was found for those juices stored in oxygen permeable container than other one. The oxidation of anthocyanins in the presence of oxygen is a possible explanation for these losses. Anthocyanin content of the samples reduced significantly during storage. Reduction rates of anthocyanin contents of the samples were faster than those of the other quality parameters. At the end of 12 months storage, the average loss level of anthocyanin was calculated as $90 \%$ in the dried pomegranate aril. The highest anthocyanin loss was observed in freze dried sample, followed by sun dried, convective and vacuum oven dried ones in descending order. During the storage, there were also significant differences between each storage time of any drying methods. These results could be explained by the fact that individual applications of each factor were not effective in preventing changes in the total anthocyanin contents during storage compared with combined treatments. As a result, to control anthocyanin loss in dried pomegranate aril during storage, combined treatment is a good way compared to each applications alone. Anthocyanin stability was found to be affected by a number of factors including storage temperature and time (Buckow et al 2010; Hellström et al 2013). Both of these studies showed that anthocyanin's lost amount was increased with increasing storage temperature and time. Our findings agree well with these literature findings.

Antioxidant activity of the samples was also affected significantly from drying process, packaging atmosphere and storage time (Table 6). Antioxidant activity of the dried pomegranate arils with repect to drying methods, packaging atmosphere and storage time were given in Figure 3.

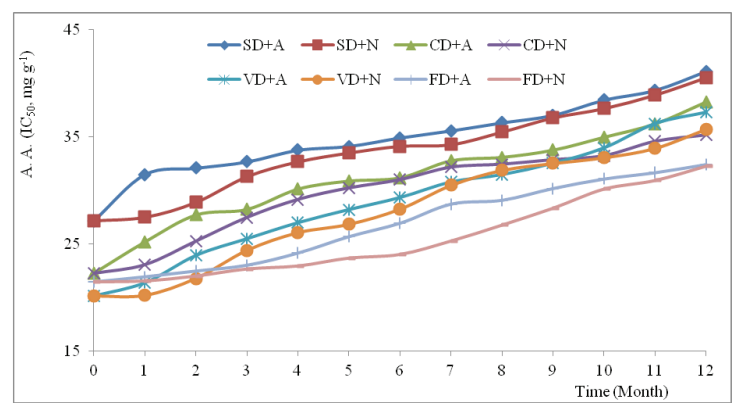

Figure 3- Antioxidant activity $\left(\mathrm{IC}_{50}\right)$ values of dried pomegranate aril with respect to drying process, packaging atmosphere and storage time

Şekil 3- Kurutma yöntemi, paketleme atmosferi ve depolama süresine göre örneklerin antioksidan aktivite değerleri

The highest antioxidant activity value was determined in freeze drying samples and this one followed by vacuum oven, convective drying and sun drying, in descending order. Wojdylo et al (2009) reported that there was a significant decrease in antioxidant activity of the products. They found that freeze dried samples had higher antioxidant 
Table 6- Duncan multiple comparision test result of antioxidant activity values of dried pomegranate aril with respect to drying process, packaging atmosphere and storage time (mean $\pm \mathrm{SE}$ )

Çizelge 6- Kurutma yöntemi, paketleme atmosferi ve depolama süresine göre örneklerin antioksidan aktivite değerlerine ait duncan çoklu karşılaştırma testi sonuçları (ortalama $\pm \mathrm{SH}$ )

\begin{tabular}{|c|c|c|c|c|c|c|}
\hline & \multicolumn{4}{|c|}{ Drying methods } & \multicolumn{2}{|c|}{ Packaging atmosphere } \\
\hline & $S D$ & $C D$ & $V D$ & $F D$ & Air & Nitrogen \\
\hline & $34.32^{a} \pm 0.58$ & $30.50^{b} \pm 0.62$ & $28.55^{c} \pm 0.75$ & $26.16^{d} \pm 0.55$ & $30.46^{a} \pm 0.53$ & $29.30^{b} \pm 0.53$ \\
\hline $\begin{array}{c}\text { Storage time } \\
\text { (months) }\end{array}$ & \multicolumn{3}{|c|}{ A.A. $\left(I C 50, m g g^{-1}\right)$} & $\begin{array}{c}\text { Storage time } \\
\text { (months) }\end{array}$ & \multicolumn{2}{|c|}{ A.A. $\left(I C 50, \mathrm{mg} \mathrm{g}^{-1}\right)$} \\
\hline 0 & \multicolumn{3}{|c|}{$22.73^{\mathrm{j}} \pm 0.80$} & 7 & \multicolumn{2}{|c|}{$31.23^{\mathrm{e}} \pm 0.83$} \\
\hline 1 & \multicolumn{3}{|c|}{$24.02^{\mathrm{j}} \pm 0.97$} & 8 & \multicolumn{2}{|c|}{$32.04^{\mathrm{de}} \pm 0.82$} \\
\hline 2 & \multicolumn{3}{|c|}{$25.50^{1} \pm 0.96$} & 9 & \multicolumn{2}{|c|}{$32.98^{\mathrm{cd}} \pm 0.79$} \\
\hline 3 & \multicolumn{3}{|c|}{$26.88^{\mathrm{h}} \pm 0.97$} & 10 & \multicolumn{2}{|c|}{$34.05^{\mathrm{bc}} \pm 0.78$} \\
\hline 4 & \multicolumn{3}{|c|}{$28.21^{\mathrm{g}} \pm 1.01$} & 11 & \multicolumn{2}{|c|}{$35.21^{\mathrm{b}} \pm 0.78$} \\
\hline 5 & \multicolumn{3}{|c|}{$29.12^{\mathrm{fg}} \pm 0.96$} & 12 & \multicolumn{2}{|c|}{$36.58^{a} \pm 0.86$} \\
\hline 6 & \multicolumn{3}{|c|}{$29.95^{f} \pm 0.95$} & & & \\
\hline
\end{tabular}

a-j, mean in the same row for drying method and packaging atmosphere, mean in the columns for storage time with different letters are significantly different $(\mathrm{P}<0.05)$

activity than vacuum drying and vacuum-microwave drying. Vashisth et al (2011) also reported that high temperature drying process could cause a decrease in antioxidant activity for muscadine pomace. Our finding is consistent with the findings of these authors. Antioxidant capacity of the samples under nitrogen gas atmosphere was higher than those of the atmospheric condition. Christopoulos \& Tsantili (2011) observed that, antioxidant activity of the dried walnuts stored under nitrogen gas were higher than that stored under atmospheric oxygen. Our finding agree with these literature results. Antioxidant activity values of the samples increased significantly during storage period. There was $40 \%$ changed in antioxidant value of the samples for 12 months storage. The same effect was determined by Tsantili et al (2011) for antioxidant activity in dried pistachio nuts.

CIE L, b* colour values with respect to drying methods, packaging atmosphere and storage time were given in Table 7. CIE L colour values of the dried pomegranate arils changed in a narrow range with respect to other colour values. The effect of drying methods on $\mathrm{L}$ colour value was significantly important. On the other hand the L colour value changed only $4.5 \%$. The lowest value was measured as 32.00 in vacuum oven dried samples, followed by convective oven, freeze dryer and sun dried samples in ascending order. And, L colour value difference between convective oven and freeze dryer samples was not statistically significant. The effect of drying method on $b^{*}$ colour values was also significant, but, the just opposite of $a^{*}$ colour value change. This situation suggest that the loss in redness $\left(\mathrm{a}^{*}\right)$ leads to appearance of product yellowness (increase in $b^{*}$ ). The highest $b^{*}$ colour value was determined as 4.45 on sun dried sample followed by convective oven, vacuum oven and freeze dried samples, in descending order. The $b^{*}$ colour value of the sample packed under nitrogen was higher than that of the other one. The effect of storage time on CIE b* colour value of the samples was also significant. The overall CIE b* colour value increased approximately $80 \%$ from the beginning to the end of the storage. Singh et al (2007) studied the effects of different aril separation techniques on some quality parameters of dried pomegranate aril (anardana). They found that CIE L, a*, $b^{*}$ colour values of the products ranged between 29.11-33.92, 10.18-11.70 and 12.42-15.15, respectively. Our results showed similarities with $\mathrm{L}$ and $\mathrm{a}^{*}$ colour values of these products.

CIE $\mathrm{a}^{*}, \mathrm{C}$ and $\mathrm{h}$ colour values were affected significantly from drying methods $\mathrm{x}$ packaging 
Table 7- Duncan multiple comparison test result of CIE $\mathbf{L}, b^{*}$ colour values of the products with respect to drying process, packaging atmosphere and storage time (mean $\pm \mathrm{SE})$

Çizelge 7- Kurutma yöntemi, paketleme atmosferi ve depolama süresine göre örneklerin CIE L, $b$ * renk değerlerine ait duncan çoklu karşılaştırma testi sonuçları (ortalama \pm SH)

\begin{tabular}{ccccccc}
\hline & \multicolumn{4}{c}{ Drying methods } & \multicolumn{2}{c}{ Packaging atmosphere } \\
\hline & $S D$ & \multicolumn{2}{c}{$C D$} & $V D$ & $F D$ & \multicolumn{2}{c}{ Air } & Nitrogen \\
\hline$L$ & $33.15^{\mathrm{a}} \pm 0.12$ & $32.51^{\mathrm{b}} \pm 0.14$ & $32.00^{\mathrm{c}} \pm 0.14$ & $32.60^{\mathrm{b}} \pm 0.13$ & $32.60^{\mathrm{a}} \pm 0.11$ & $32.53^{\mathrm{a}} \pm 0.09$ \\
\hline$b^{*}$ & $4.45^{\mathrm{a}} \pm 0.12$ & $4.38^{\mathrm{a}} \pm 0.13$ & $3.82^{\mathrm{b}} \pm 0.11$ & $3.85^{\mathrm{b}} \pm 0.11$ & $3.93^{\mathrm{b}} \pm 0.08$ & $4.32^{\mathrm{a}} \pm 0.09$ \\
\hline $\begin{array}{c}\text { Storage time } \\
\text { (months) }\end{array}$ & $L$ & $b^{*}$ & $\begin{array}{c}\text { Storage time } \\
\text { (months) }\end{array}$ & $L$ & $b^{*}$ \\
\hline 0 & $32.42^{\mathrm{a}} \pm 0.27$ & $2.93^{\mathrm{h}} \pm 0.10$ & 7 & $32.44^{\mathrm{a}} \pm 0.21$ & $4.25^{\text {def }} \pm 0.15$ \\
1 & $32.76^{\mathrm{a}} \pm 0.33$ & $3.41^{\mathrm{h}} \pm 0.19$ & 8 & $32.45^{\mathrm{a}} \pm 0.19$ & $4.43^{\text {cde }} \pm 0.16$ \\
2 & $32.53^{\mathrm{a}} \pm 0.28$ & $3.60^{\mathrm{gh}} \pm 0.22$ & 9 & $32.80^{\mathrm{a}} \pm 0.25$ & $4.58^{\mathrm{bcd}} \pm 0.18$ \\
3 & $32.38^{\mathrm{a}} \pm 0.27$ & $3.71^{\mathrm{gh}} \pm 0.18$ & 10 & $32.65^{\mathrm{a}} \pm 0.22$ & $4.78^{\mathrm{abc}} \pm 0.16$ \\
4 & $32.54^{\mathrm{a}} \pm 0.26$ & $3.77^{\text {fgh }} \pm 0.16$ & 11 & $32.86^{\mathrm{a}} \pm 0.21$ & $4.97^{\mathrm{ab}} \pm 0.19$ \\
5 & $32.71^{\mathrm{a}} \pm 0.24$ & $3.91^{\text {efgh }} \pm 0.15$ & 12 & $32.29^{\mathrm{a}} \pm 0.33$ & $5.21^{\mathrm{a}} \pm 0.15$ \\
6 & $32.57^{\mathrm{a}} \pm 0.27$ & $4.08^{\text {egh }} \pm 0.16$ & & & \\
\hline
\end{tabular}

${ }^{\mathrm{a}-1}$, mean in the same row for drying method and packaging atmosphere, columns for storage time with different letters are significantly different $(\mathrm{P}<0.05)$

Table 8- Duncan multiple comparison test result of CIE $a^{*}, \mathrm{C}$ and $\mathrm{h}$ colour values of the products with respect to drying process $x$ packaging atmosphere (mean $\pm \mathrm{SE}$ )

Çizelge 8- Kurutma yöntemi x paketleme atmosferine göre örneklerin CIE $a^{*}, C$ ve h renk değerlerine ait duncan çoklu karşılaştırma testi sonuçları (ortalama $\pm S H$ )

\begin{tabular}{|c|c|c|c|c|c|c|}
\hline $\begin{array}{l}\text { Drying } \\
\text { methods }\end{array}$ & $\begin{array}{l}\text { Air } \\
a^{*}\end{array}$ & $\begin{array}{c}\text { Nitrogen } \\
a^{*}\end{array}$ & $\begin{array}{c}\text { Air } \\
C\end{array}$ & $\begin{array}{c}\text { Nitrogen } \\
C\end{array}$ & $\begin{array}{c}\text { Air } \\
h\end{array}$ & $\begin{array}{c}\text { Nitrogen } \\
h\end{array}$ \\
\hline SD & $6.85^{\mathrm{cA}} \pm 0.31$ & $6.89^{\mathrm{aA}} \pm 0.29$ & $8.23^{\mathrm{cA}} \pm 0.21$ & $8.38^{\mathrm{dA}} \pm 0.19$ & $33.31^{\mathrm{aA}} \pm 2.00$ & $34.27^{\mathrm{aA}} \pm 1.95$ \\
\hline $\mathrm{CD}$ & $8.15^{\mathrm{bB}} \pm 0.30$ & $10.03^{\mathrm{bA}} \pm 0.34$ & $9.21^{\mathrm{bB}} \pm 0.26$ & $11.11^{\mathrm{bA}} \pm 0.30$ & $27.31^{\mathrm{bA}} \pm 1.43$ & $25.33^{\mathrm{bA}} \pm 1.25$ \\
\hline VD & $8.50^{\mathrm{bA}} \pm 0.35$ & $9.36^{\mathrm{bA}} \pm 0.40$ & $9.37^{\mathrm{bA}} \pm 0.29$ & $10.23^{\mathrm{cA}} \pm 0.34$ & $24.63^{\mathrm{bA}} \pm 1.50$ & $23.62^{\mathrm{bA}} \pm 1.53$ \\
\hline FD & $10.16^{\mathrm{aA}} \pm 0.40$ & $11.30^{\mathrm{aA}} \pm 0.41$ & $10.81^{\mathrm{aB}} \pm 0.37$ & $12.11^{\mathrm{aA}} \pm 0.36$ & $19.94^{\mathrm{cA}} \pm 1.15$ & $20.92^{\mathrm{bA}} \pm 1.27$ \\
\hline
\end{tabular}

A-B , mean in the same row with different upper case letters are significantly different $(\mathrm{P}<0.05)$; ${ }^{\mathrm{a}-\mathrm{d}}$, mean in the same column with different lower case letters are significantly different $(\mathrm{P}<0.05)$

atmosphere interaction (Table 3, Table 8). The highest change was examined in a* colour value due to drying, packaging and storage time with respect to other colour components. CIE a* colour value gives an idea about the redness of the product and also correlate with anthocyanin content (Fisher et al 2013). The highest overall a* colour value for drying was measured in freeze dried samples (10.73) followed by convective, vacuum oven and sun dried samples in descending order. This phenomenon could be a result of heat damage and also process exposure time on anthocyanins. There is correlation between anthocyanin content and $\mathrm{a}^{*}$ colour value of any product as mentioned above. The overall a* colour value of the sample packed under nitrogen was 9.93 and this value measured as 8.84 for packed samples under atmospheric condition. This situation showed that $\mathrm{a}^{*}$ colour value was more stable under nitrogen gas. On the other hand, these results could not be explained by the individual applications of each factor. The combined effects of drying methods and packaging atmosphere were more pronounced than individual application of these factors in preventing changes in the $\mathrm{a}^{*}$ colour values 
Table 9- Duncan multiple comparison test result of $h$ colour values of the products with respect to drying process $\mathrm{x}$ storage time (mean $\pm \mathrm{SE})$

Çizelge 9- Kurutma yöntemix depolama süresine göre örneklerin h renk değerlerine ait duncan çoklu karşılaştırma testi sonuçlarl (ortalama $\pm \mathrm{SH}$ )

\begin{tabular}{|c|c|c|c|c|}
\hline \multirow{2}{*}{$\begin{array}{c}\text { Storage time } \\
\text { (months) }\end{array}$} & \multicolumn{4}{|c|}{ Drying methods } \\
\hline & $S D$ & $C D$ & $V D$ & $F D$ \\
\hline 0 & $17.16^{1 \mathrm{~A}} \pm 0.95$ & $12.53^{1 \mathrm{~B}} \pm 0.04$ & $13.86^{\mathrm{gB}} \pm 0.66$ & $11.97^{\mathrm{kB}} \pm 0.61$ \\
\hline 1 & $22.09^{\mathrm{hA}} \pm 1.97$ & $19.27^{\mathrm{hAB}} \pm 0.89$ & $16.25^{\mathrm{fgBC}} \pm 1.60$ & $13.89^{\mathrm{jkC}} \pm 1.20$ \\
\hline 2 & $24.78^{\mathrm{ghA}} \pm 1.98$ & $21.30^{\mathrm{ghAB}} \pm 1.38$ & $17.08^{\mathrm{fgBC}} \pm 1.78$ & $14.73^{\mathrm{jkC}} \pm 0.67$ \\
\hline 3 & $26.65^{\mathrm{fgA}} \pm 0.30$ & $22.92^{\mathrm{fghB}} \pm 0.92$ & $17.67^{\mathrm{fgC}} \pm 1.31$ & $15.97^{\text {hijc }} \pm 0.74$ \\
\hline 4 & $28.62^{\mathrm{fA}} \pm 0.63$ & $23.11^{\mathrm{fgB}} \pm 1.51$ & $18.55^{\mathrm{fC}} \pm 1.55$ & $17.47^{\mathrm{ghlC}} \pm 0.85$ \\
\hline 5 & $29.85^{\mathrm{fA}} \pm 1.70$ & $24.84^{\mathrm{efgB}} \pm 1.16$ & $19.64^{\mathrm{fC}} \pm 0.80$ & $18.44^{\mathrm{fghC}} \pm 1.59$ \\
\hline 6 & $33.84^{\mathrm{eA}} \pm 0.33$ & $25.87^{\mathrm{defB}} \pm 1.69$ & $25.18^{\mathrm{eB}} \pm 2.35$ & $19.85^{\operatorname{efg} C} \pm 0.61$ \\
\hline 7 & $35.58^{\mathrm{deA}} \pm 0.92$ & $28.15^{\mathrm{cdeB}} \pm 1.12$ & $25.43^{\mathrm{eB}} \pm 1.12$ & $20.90^{\mathrm{defC}} \pm 0.82$ \\
\hline 8 & $38.35^{\mathrm{cdA}} \pm 1.21$ & $29.15^{\mathrm{cdB}} \pm 1.93$ & $26.86^{\mathrm{deB}} \pm 0.52$ & $22.37^{\mathrm{cdeC}} \pm 0.86$ \\
\hline 9 & $40.78^{\mathrm{cA}} \pm 0.80$ & $30.55^{\mathrm{bcB}} \pm 1.38$ & $29.37^{\mathrm{cdB}} \pm 0.83$ & $23.37^{\mathrm{cdC}} \pm 1.15$ \\
\hline 10 & $44.59^{\mathrm{bA}} \pm 0.44$ & $33.45^{\mathrm{abB}} \pm 1.10$ & $32.17^{\mathrm{bcB}} \pm 0.99$ & $25.52^{\mathrm{bcC}} \pm 1.23$ \\
\hline 11 & $46.41^{\mathrm{bA}} \pm 0.83$ & $34.60^{\mathrm{aB}} \pm 0.93$ & $34.38^{\mathrm{abB}} \pm 1.2$ & $28.41^{\mathrm{bC}} \pm 1.86$ \\
\hline 12 & $50.57^{\mathrm{aA}} \pm 1.31$ & $36.45^{\mathrm{aB}} \pm 0.50$ & $37.18^{\mathrm{aB}} \pm 0.68$ & $32.77^{\mathrm{aC}} \pm 1.11$ \\
\hline
\end{tabular}

${ }_{\mathrm{A}-\mathrm{C}}$, mean in the same row with different upper case letters are significantly different $(\mathrm{P}<0.05)$; ${ }^{\mathrm{a}-\mathrm{k}}$, mean in the same column with different lower case letters are significantly different $(\mathrm{P}<0.05)$

of the samples. The overall a* colour values of the samples significantly changed during storage. While $a^{*}$ value was 12.03 at the beginning of storage, it decreased to 6.54 at the end of 12 months storage. Perez-Vicente et al (2004) found that a* value of pomegranate juice significantly decreased during processing and storage. Another study carried out on dried persimmon by Tülek \& Demiray (2014). They reported that drying process caused deterioration on persimmon colour values with respect to drying temperature and application time.

The highest overall chroma value for drying method was measured as 11.46 in freeze dried samples and this one followed by convective oven, vacuum oven and sun dried samples in descending order. These values also showed that totally the highest colour loss was observed in sun dried samples. The effect of packaging atmosphere has also significant. While the average chroma value of the samples packed under nitrogen was 10.46, the chroma value of the sample were determined as 9.40 for packed under atmospheric condition. These results could be explained by the fact that individual applications of drying methods and packaging atmosphere were not effective in controlling changes in the $\mathrm{C}$ values compared with combined treatments. As a result, to prevent $\mathrm{C}$ value changes in dried pomegranate aril, combined treatment is a good way compared to each applications alone. C colour value was decreased $32 \%$ from the beginning of storage to end of 12 months storage.

The highest overall hue angle value was calculated as 33.79 in sun dried samples and this one followed by convective oven, vacuum oven and freeze dried samples. The packaging atmosphere had no significant effect on hue angle value of the sample. The effect of drying methods $\mathrm{x}$ storage time and packaging atmosphere $\mathrm{x}$ storage time interactions on hue angle colour value of the samples were significant. During storage, there were significant differences between drying methods with respect to hue angle values at each storage time (Table 9). In addition to this results, statistical differences were also found between storage times in each drying methods. In order to prevent changes in the hue angle value during storage, combined treatment was more effective than each alone application. 


\section{Conclusions}

Hicaznar cultivar could be processed into dried pomegranate aril, and obtained product ratio was approximately $10 \%$ from fresh fruit for this cultivar. According to the analyzed quality parameters, freeze drying was the best one in dried pomegranate aril production among the drying methods and followed by vacuum oven drying. On the other hand, during freeze drying process, some physical damage occurred on the aril surface. Vacuum oven and convective drying methods could be advised in dried pomegranate aril production. Some quality loss in the products was observed during storage. Packaging atmosphere also had significant effect on the product quality. Packaging under nitrogen gas could be recommended as compared to packaging under air. As a conclusion, Hicaznar cultivar could be processed into dried aril as an alternative to juice like products. These dried pomegranate arils have some advantages such as high shelf stability and functional properties.

\section{Acknowledgements}

I am grateful to the General Directorate of Agricultural Research and Policy of Turkey (TAGEM), Project No TAGEM/GY/11/03/01/187, for financial support.

\section{References}

Albrecht M, Jiang W, Kumi-Diaka J, Lansky E P, Gommersall L M, Patel A, Mansel R E, Neman I, Geldof A A \& Campbell M J (2004). Pomegranate extracts potently suppress proliferation, xenograft growth, and invasion of human prostate cancer cells. Journal of Medicinal Food 7(3): 274-283

AOAC (2005). Official Methods of Analysis. Washington, DC, USA: Association Official Analytical Chemists

Arao K, Wnag Y M, Inoue N, Hirata J, Cha J Y, Nagao K \& Yanagita T (2004). Dietary effect of pomegranate seed oil rich in 9 cis, 11 trans, 13 cis conjugated linolenic acid on lipid metabolism in obese, hyperlipidemic OLETF rats. Lipids in Health Disease 3(24): 1-7

Asafi N \& Cemeroğlu B (2000). Vişne ve nar suyu ve konsantratlarında antosiyaninlerin degradasyonu. Gida 25(6): 407-411

Buckow R, Kastell A, Terefe N S \& Versteeg C (2010). Pressure and temperature effects on degradation kinetics and storage stability of total anthocyanins in blueberry juice. Journal of Agricultural and Food Chemistry 58: 10076-10084

Calín-Sánchez Á, Figiel A, Hernández F, Melgarejo P, Lech K \& Carbonell-Barrachina Á A (2013). Chemical composition, antioxidant capacity, and sensory quality of pomegranate (Punica granatum L.) arils and rind as affected by drying method. Food and Bioprocess Technology 6: 1644-1654

Cemeroğlu B (2010). Gıda Analizleri. G1da Teknolojisi Derneği Yayınları No: 34, Ankara, Turkey

Cemeroğlu B \& Artık N (1990). Isıl işlem ve depolama koşullarının nar antosiyaninleri üzerine etkisi. Gıda 15(1): 13-19

Christopoulos MV \& Tsantili E(2011). Effects of temperature and packaging atmosphere on total antioxidants and colour of walnut (Juglans regia L.) kernels during storage. Scientia Horticulturae 131: 49-57

Du C T, Wang P L \& Francis F J (1975). Anthocyanins of pomegranate, Punica granatum. Journal of Food Science 40: 417-418

Egan H, Kirk R S \& Sawyer R (1981). Pearson's Chemical Analysis of Foods. Longman Inc., New York, pp.591

Escarpa A \& Gonzales M C (2001). Approach to the content of total extractable phenolic compounds from different food samples by comparision of chromatographic and spectrophotometric methods. Analytica Chimica Acta 427: 119-127

Fadavi A, Barzegar M \& Azizi M H (2006). Determination of fatty acids and total lipid content in oilseed of 25 pomegranates varieties grown in Iran. Jounal of Food Composition and Analysis 19(6-7): 676-680

Fischer U A, Carle R \& Kammerer D R (2013). Thermal stability of anthocyanins and colourless phenolics in pomegranate (Punica granatum L.) juices and model solutions. Food Chemistry 138: 1800-1809

Gil M I, Martinez J A \& Artes F (1996). Minimally processed pomegranate seeds. LWT-Food Science and Technology 29: 708-713

Gil M I, Tomas-Barberan F A, Pierce B H, Holcroft D M \& Kader A A (2000). Antioxidant activity of pomegranate juice and its relationship with phenolic composition and processing. Journal of Agricultural and Food Chemistry 48: 4581-4589

Gölükcü M, Tokgöz H \& Kıralan M (2008). Ülkemizde yetiştirilen önemli nar (Punica granatum) çeşitlerine ait çekirdeklerin bazı özellikleri. Glda 33(6):1-12

Hellström J, Mattila P \& Karjalainen R (2013). Stability of anthocyanins in berry juices stored at different temperatures. Journal of Food Composition and Analysis 31: 12-19 
Hernandez F, Melgarejo P, Tomas-Barberan F A \& Artes F (1999) Evolution of juice anthocyanins during ripening of new selected pomegranate (Punica granatum) clones. European Food Research and Technology 210: 39-42

Hora J J, Maydew E R, Lansky E P \& Dwivedi C (2003). Chemopreventive effects of pomegranate seed oil on skin tumor development in CD1 mice. Journal of Medicinal Food 6(3): 157-161

Jaiswal V, Dermarderosian A \& Porte J R (2010). Anthocyanins and polyphenol oxidase from dried arils of pomegranate (Punica granatum L.). Food Chemistry 118: 11-16

Kıralan M, Gölükcü M \& Tokgöz H (2009). Oil content and CLA content of seeds from important pomegranate cultivars (Punica granatum L.) grown in Turkey. Journal of American Oil Chemists 'Society 86(10): 985-990

Kingsly A R P \& Singh D B (2007). Drying kinetics of pomegranate arils. Journal of Food Engineering 79: 741-744

Kingsly A R P, Singh D B, Manikantan M R \& Jain R K (2006). Moisture dependent physical properties of dried pomegranate seeds (Anardana). Journal of Food Engineering 75: 492-496

Lafka T I, Sinanoglou V \& Lazos E S (2007). On the extraction and antioxidant activity of phenolic compounds from winery wastes. Food Chemistry 104(3): 1206-1214

Maier T, Fromm M, Schieber A, Kammere D R \& Carle R (2009). Process and storage stability of anthocyanins and non-anthocyanin phenolics in pectin and gelatin gels enriched with grape pomace extracts. European Food Research and Technology 229(6): 949-960

Michalczyk M, Macura R \& Matuszak I (2009). The effect of air-drying, freeze-drying and storage on the quality and antioxidant activity of some selected berries. Journal of Food Processing and Preservation 33: $11-21$

Naczk M \& Shahidi F (2006). Phenolics in cereals, fruits and vegetables: Occurrence, extraction and analysis. Journal of Pharmaceutical and Biomedical Analysis 41(5): 1523-1542

Özdemir M (2001) Mathematical analysis of color changes and chemical parameters of roasted hazelnuts. PhD, Istanbul Technical University, İstanbul, Turkey.

Perez-Vicente A, Serrano P, Abellan P \& Garcia-Viguera $C$ (2004). Influence of packaging material on pomegranate juice colour and bioactive compounds, during storage. Journal of The Science and Food Agriculture 84: 639-644
Poyrazoğlu E, Gökmen V \& Artık N (2002). Organic acid and phenolic compounds in pomegranates (Punica granatum L.) grown in Turkey. Journal of Food Composition and Analysis 15(5): 567-575

Schubert S Y, Lansky E P \& Neeman I (1999). Antioxidant and eicosanoid enzyme inhibition properties of pomegranate seed oil and fermented juice flavonoids. Journal of Ethnopharmacology 66: 11-17

Singh D B, Kingsly A R P \& Jain R K (2007). Studies on seperation techniques of pomegaranate arils and their effect on quality of anardana. Journal of Food Engineering 79: 671-674

Sogi D S, Siddiq M, Greiby I \& Dolan K D (2013). Total phenolics, antioxidant activity, and functional properties of 'Tommy Atkins' mango peel and kernel as affected by drying methods. Food Chemistry, 141: 2649-2655

Spanos G A \& Wrolstad R E (1990). Influence of processing and storage on the phenolic composition of thompson seedless grape juice. Journal of Agricultural and Food Chemistry 38(3): 817-824

Tsantili E, Konstantinidis K, Christopoulos M V \& Roussos P A (2011). Total phenolics and flavonoids and total antioxidant capacity in pistachio (Pistachia vera L.) nuts in relation to cultivars and storage conditions. Scientia Horticulturae 129: 694-701

TUIK (2012). Tarımsal Yap1 (Üretim, Fiyat, Değer). TUIK, Turkey

Tülek Y \& Demiray E (2014). Sicak hava kurutma yönteminde farklı sıcaklık ve ön işlemlerin Trabzon hurmasının renk ve kuruma karakteristiklerine etkisi. Tarım Bilimleri Dergisi-Journal of Agricultural Sciences 20: 27-37

Vardin H (2000). Harran Ovasında yetişen değişik nar çeşitlerinin gıda sanayinde kullanım olanakları üzerine bir çalışma. PhD, Çukurova Universitesi, Fen Bilimleri Enstitüsü (Basılmamış), Adana, Turkey

Vardin H \& Abbasoğlu M (2004). Nar Ekşisi ve Narın diğer değerlendirilme olanakları. Geleneksel Gidalar Sempozyumu, Van, Turkey, s: 165-169

Varian (1989). Analytical Methods. Varian Australia Pty. Ltd. Mutgrave Victoria, Publication No: 85, Australia

Vashisth T, Singh R K \& Pegg R B (2011). Effects of drying on the phenolics content and antioxidant activity of muscadine pomace. LWT - Food Science and Technology 44: 1649-1657

Wojdylo A, Figiel A \& Oszmianski J (2009). Effects of drying methods with the application of vacuum microwaves on the bioactive compounds, color, and antioxidant activity of strawberry fruits. Journal of Agricultural and Food Chemistry 57: 1337-1343 